\title{
Danmark skal lede et EU på afgrundens rand
}

Jens Bostrup

\section{Helle Thorning-Schmidt har lovet et ambitiøst dansk formandskab. Men hvis hun til sommer} bare kan konstatere, at EU-samarbejdet er nogenlunde intakt og der ikke kom en ny finanskrise under den danske vagt, vil det være en stor bedrift

En ellers kølig, velovervejet og saglig ukrainsk aktivist mister fatningen et øjeblik og kan slet ikke skjule sin begejstring, da hun hører, hvor jeg kommer fra.

"Du er fra København! Du bor der... Det er for sejt, du må være vildt stolt...".

Den danske hovedstad er kendt ude østpå. I alle de lande, der håber en dag at blive en del den Europæiske Union, er magthaverne udmærket klar over, at man skal leve op til københavnerkriterierne, før man kan gå i gang med forhandlingerne: Man skal være en demokratisk retsstat, der respekterer menneskerettighederne og beskytter mindretal. Og magthaverne bliver holdt til ilden af demokratisk sindede reformpolitikere og aktivister, for hvem kø- benhavnerkriterierne er deres vigtigste våben. De blev vedtaget på topmødet under det forrige danske formandskab i 1993 under Poul Nyrup Rasmussens ledelse.

Det næste danske formandskab satte ikke mindre aftryk. Anders Fogh Rasmussen kunne efter flere døgns hårde forhandlinger i København byde velkommen til 10 øst- og centraleuropæiske lande. Fogh betegnede selv topmødet i København 2002 som "åbningen af et nyt kapitel Europas historie”.

"Europa spreder sine vinger. I Frihed. I velstand. Og i fred. Det er I sandhed et stolt øjeblik for den Europæiske Union. En triumf for frihed og demokrati”, sagde Fogh, da han afsluttede topmødet.

Helle Thorning-Schmidt vil næp- 
pe få brug for at finde helt så store ord frem, når hun til juni afslutter det danske formandskab 2012.

Der er ellers masser af vigtige ting på programmet, der godt kan kalde på store ord. Vi står midt i den værste økonomiske krise siden depressionen i 1930'erne, som har udløst tre andre kriser: En gældskrise, en ledelseskrise og en tillidskrise, som hver for sig truer med at få det europæiske samarbejde, som vi kender det, til at falde fra hinanden. $\mathrm{Og}$ som alle skal håndteres under det danske formandskab.

\section{Grækenlands gældskrise}

Gældskrisen, der begyndte i Grækenland, udvikler sig med rasende fart dag for dag. I maj 2010 fik grækerne den første hjælpepakke til en værdi af mere end 750 milliarder kroner. I juli 2011 kom endnu en pakke til næsten 800 milliarder. Blot tre måneder senere, i oktober 2011, blev det nødvendigt at skære halvdelen af gælden og lade bankerne tage tabet på omkring 750 milliarder kroner.

Håbet er, at grækerne nu kan holde sig flydende, men det kræver, at de også gennemfører en lang række drakoniske økonomiske reformer, herunder nedskæringer af pensioner og lønninger og skatteforhøjelser.

Hvis det mislykkes, må EU- og eurolandene enten komme med endnu en hjælpepakke - i givet fald den fjerde i løbet af to år - eller lade den græske stat gå bankerot med risiko for, at det vil udløse en ny finanskrise, der meget vel kan trække resten af verden med ned.

Den side af sagen skal EU's formandskab i princippet blande sig udenom; det et en sag mellem grækerne og eurogruppens økonomiske regering.

EU's formandskab skal i princippet heller ikke blande sig i, hvordan man undgår, at investorerne bliver betænkelige ved at låne penge til Spanien, Italien og Frankrig, der også er plaget af underskud og gæld - nu hvor det har vist sig, at man kan miste halvdelen af sine penge på at investere i et euroland.

Det skal i første omgang løses ved at 'geare' eurogruppens fælles redningsfond og få flere - især kineserne - til at spytte penge i kassen. $\mathrm{Og}$ det er en sag for eurogruppens økonomiske regering.

Men det betyder ingenlunde, at danskerne kan ånde lettet op og koncentrere sig om andre ting. Den græske gældskrise spiller direkte ind på EU's dagsorden på flere måder. Blandt de vigtigste er:

At redde bankerne fra at gå fallit på de græske tab. At hanke op i medlemslandenes økonomiske politik, og at holde sammen på EU.

\section{Red bankerne}

Bankerne mister 750 milliarder kroner på den græske gældsnedskriv- 
ning. Det rammer især græske og franske, men også tyske banker. Konkurser, eller bare risikoen for at de kan komme, kan udløse en ny finanskrise.

EU-lederne har derfor besluttet, at bankerne skal være bedre polstret, så de kan overleve de store tab. Inden 30. juni næste år - altså ved udløbet af det danske formandskab - skal bankerne have skaffet pengene.

Det er imidlertid en smule uklart, hvorfra pengene skal komme. EU-lederne har besluttet, at bankerne i første omgang skal skaffe så mange penge som muligt på markedet, men ifølge Charles Dallar, direktør for International Institute of Finance, der repræsenterer bankerne, er det alt for dyrt.

Bankerne vil derfor gå en anden vej for at nå målet: For dem kan det langt bedre betale sig at nedbringe udlånet - dermed vil kravet om en bedre balance mellem kapital og udlån blive nået. En hurtig og enkel vej til at nedbringe de mest risikable udlån er at sælge, hvad man ligger inde med af sydeuropæiske statsobligationer, advarer Dallar i et brev til G20-landenes statschefer.

Det var ikke meningen. Dermed vil renterne stige og gøre det dyrere for de i forvejen kriseramte sydeuropæiske lande at låne penge.

"Det er lige det modsatte af målet, som er at stabilisere og understøtte statsgælden i Europa”, som Charles Dallar skriver til G20-lederne.
Og i det omfang bankerne også nedbringer udlån til private og virksomheder, vil det begrænse væksten i samfundet.

Det problem havde EU-lederne godt set, da de traf beslutningen, og de har også forberedt sig på, at det langt fra vil lykkes at hente pengene på det private marked.

Så der er ingen vej uden om, at det offentlige må træde til og skyde penge i bankerne (endnu en gang). Problemet er nu, at hvis Spanien, Italien, Portugal og Irland skal hælde penge i bankerne (enten direkte eller via den fælles redningsfond), så kan de miste kreditværdighed. Det betyder højere renter og kan blive begyndelsen på en ond spiral.

Frankrigs position er en anden udfordring. Landets kreditværdighed er lige nu i top (AAA), og præsident Nicolas Sarkozy, der er på genvalg i april-maj, har sat sin politiske prestige ind på at bevare topkarakteren.

Men kreditvurderingsbureauerne har gjort det klart, at den franske AAA-karakter hænger i en tynd tråd. Og hvis den franske stat skal sende milliarder af euro efter bankerne (enten direkte eller via euroens krisefond, EFSF) kan det være nok til udløse en nedgradering, ikke mindst fordi de franske banker har satset mange penge på Grækenland.

$\varnothing$ konomiminister Margrethe Vestager må altså balancere mellem at udløse en ny finanskrise, hvis bankerne bukker under for de græske 
tab, eller vælte den franske præsident. Ikke nogen taknemmelig opgave.

\section{Six pack}

Den anden store opgave, der følger direkte af gældskrisen, er at få hånd i hanke med finanspolitikken i euroland og nærmeste omegn (herunder Danmark).

Den såkaldte six pack - en pakke med seks forskellige retsakter, der skal sikre EU bedre kontrol med de enkelte landes finanspolitik - blev vedtaget i efteråret, og det bliver op til det danske formandskab at sætte de nye procedurer i værk. Det kan få stor betydning for, hvordan de fremover vil blive brugt i praksis.

Blandt andet kan det danske formandskab rykke ved balancen mellem, hvor meget energi, der bliver brugt på at skabe vækst, og hvor meget man fokuserer på kontrol, disciplin og sanktioner.

Regeringen i Danmark har afsat næsten 20 milliarder kroner til at få gang i væksten herhjemme. Men de penge batter først for alvor noget, hvis Danmark sammen med resten af de mere velstående lande i Europa koordinerer deres vækstpakker.

Arbejderbevægelsens Erhvervsråd har beregnet, at pengene vil få næsten dobbelt effekt, hvis Margrethe Vestager (R) kan få sine EU-kolleger med på ideen om vækst.

AE-rådets prognose konkluderer, at en fælles indsats fra de EU-lande, der har råderummet til at reagere, vil kunne skabe 36.000 ekstra job i Danmark - og 1,2 millioner nye job i Europa.

På den anden side står Tyskland, der er mere er optaget af at genvinde investorernes tillid med økonomisk disciplin i unionen.

Her bliver det især interessant, hvordan EU-landene i praksis vil håndtere Italien - unionens tredjestørste økonomi, der med en gæld på 120 pct. af BNP og en notorisk modvilje mod at gøre noget ved det - regnes for den største risiko for en ny gældskrise.

Kan EU virkelig gennemtrumfe reformer af $\mathrm{fx}$ tilbagetrækningsalderen, som den italienske regering ikke selv ønsker?

Et fingerpeg om, hvor alvorligt eurolandene mener det, kom da lederne besluttede at åbne en permanent EU-mission i Athen, som hver eneste dag skal overvåge og rådgive den dybt forgældede græske regering om reformer.

Situationen er aldrig set før i det europæiske samarbejdes historie, og så sent som for et år siden var en sådan magtkoncentration og overordnet styring af eurolandene fuldkommen utænkelig.

\section{Holde sammen på EU}

Den tredje store opgave, der følger af gældskrisen, er at holde sammen på den europæiske union.

I krisens løb er eurolandene ryk- 
ket sammen i en magtfuld ' $ø$ konomisk regering'. Spørgsmålet er nu, om det i realiteten vil indebære en deling af EU.

"Det er forståeligt, og sågar logisk og nødvendigt, at de 17 arbejder tæt sammen om at løse problemerne i eurozonen. Men samtidig er det helt afgørende, at man ikke ødelægger det, som de 27 har skabt i den Europæiske Union", som den polske europaminister, Mikolaj Dowgielewicz, udtrykker det.

Han erkender, at EU allerede i et vist omfang er blevet et gummistempel for eurogruppen.

"Lektien, som jeg gerne vil dele med det kommende danske formandskab, er: En EU-formand, der står uden for eurozonen, kan ikke påberåbe sig at lede forhandlingerne. Det ville være falsk".

"På den anden side spiller EU-formanden faktisk en rolle. Formelt kan eurogruppen ikke træffe beslutninger om for eksempel det finansielle marked. Beslutningen skal 'gummistemples', som nogle vil udtrykke det, andre vil sige 'formaliseres' af de 27. Derfor kan formandskabet ikke bare ignorere situationen man er nødt til at holde sig informeret og forsøge at blive involveret", siger Mikolaj Dowgielewicz.

Bekymringen for, at EU i realiteten er blevet delt, fremgår klart af den lange strøm af officielle erklæringer om, at det ikke vil og ikke må ske, fordi det vil indebære, at unionen af 27 vil falde fra hinanden.
Men i realiteten har vi nu et todelt Europa, fastslår Bartek Nowak, direktør for det anerkendte Center for Internationale Relationer i Warszawa, der har fulgt det polske formandskab tæt.

"Det er ganske vist stadig Polens officielle politik, at vi skal undgå den situation. Men det er ikke desto mindre en realitet i dag. Det kan ikke benægtes", siger Bartek Nowak, som tidligere var ansat i Europa-Parlamentet, hvor han deltog i konventet, der forberedte EU's forfatningstraktat.

Nowak peger på, at de seneste ugers krisemøder mellem finansministre og statsledere har etableret et klart mønster: De lange og hårde forhandlinger finder sted blandt eurolandene, som også træffer de store beslutninger.

"Vi må gå ud fra, at den økonomiske krise også i de kommende år vil sætte dagsordenen, og at der bliver fokus på økonomiske reformer. Det indebærer, at alle store beslutninger vil blive truffet i eurozonen, hvor vi ikke er med", forklarer han.

\section{Mere integration}

Man skal ikke undervurdere den dynamik, der nu er skabt mellem eurolandene.

Finansministrene og statslederne samles med jævne og hyppige mellemrum. De har sat sig det fælles mål at skabe økonomisk bæredygtighed og konkurrenceevne for hvert 
eneste af eurogruppens medlemmer.

De har kastet alle hæmninger over bord for at nå målet. Tilsyneladende er der ingen grænser for, hvor langt de vil trænge ind i hinandens nationale anliggender.

"For bare to år siden kunne ingen forestille sig, at nogen udefra ville blande sig i de nationale budgetter, pensionsordninger, tilbagetrækningsalder, skattepolitik osv. Det gør eurolandene nu. Det er kolossale skridt i retning af mere integration, der har fundet sted", konstaterer Nowak.

Den offentlige ydmygelse af Berlusconi har vist, at end ikke regeringernes værdighed og overlevelse længere er hellig.

I denne situation skal de danske ministre altså forsøge at holde øje med, at eurogruppen ikke skaffer sig en fordel ved at aftale en fælles holdning til de emner, som er EU's kompetence og rettelig burde forhandles i EU-kredsen.

Venstres EU-ordfører, Lykke Friis, peger på dele af det indre marked, skattepolitikken og sågar EU's budget som naturlige elementer i eurogruppens diskussioner. "Tingene hænger jo sammen og bliver besluttet i sammenhæng", forklarer hun.

"Og vi oplever allerede, at eurolandenes finansministre er holdt op med at gå til møder i EU, fordi sagerne allerede er diskuteret og beslutningerne i realiteten truffet".

Statsminister Helle Thorning-
Schmidt forsikrer dog, at den danske regering vil holde skarpt øje med, at eurogruppen holder sig fra emner, der skal vedtages af de 27.

"Vi skal hele tiden påpege, at når beslutninger berører de 27 , så skal Danmark være med ved bordet", siger statsminister Helle ThorningSchmidt (S).

Hun og hendes ministre får deres sag for, hvis de ikke bare vil stille sig tilfreds med at påpege, hvad eurogruppen bør og ikke bør tale om, men også sikre sig, at den retter sig efter det.

\section{Hvis EU deles}

De ti lande uden for euroen har vidt forskellige interesser.

Storbritannien kunne ikke drømme om at gå med i euroen, men har en meget stor finansiel sektor i London at tage hensyn til. Briternes største bekymring er, at eurogruppen gør det vanskeligere for London at bevare sin status som finansiel hovedstad og flytter mere aktivitet til Frankfurt eller Paris.

Danmark har valgt at stå udenfor, men er bundet op på euroen i et omfang, der beskrives som et de facto medlemskab - dog uden indflydelse.

De østeuropæiske lande, som står udenfor, opfatter sig ikke som udenfor, men som på vej ind. Deres dilemma er nu, at de på den ene side er helt indforstået med, at stærkere integration er nødvendig for at løse 
krisen. Men på den anden side kan eurolandenes ryk gøre det sværere at komme med i euroen.

Bartek Nowak fremhæver forslaget om euroobligationer som eksempel. Det vil give de svage eurolande mulighed til at låne til en markant lavere rente, fordi eurolandene hæfter solidarisk - og altså har den tyske statskasse i ryggen.

"Det er et fremragende forslag, når det gælder om at redde eurozonen ud af krisen. Men det er også dybt skadeligt for Polen. Når euroobligationerne kommer, vil ingen længere interessere sig for polske obligationer - de bliver meget mindre værd", siger Bartek Nowak.

Dermed bliver det endnu vanskeligere for Polen at gøre sin økonomi klar til euroen.

\section{Europas skakbræt}

Dertil kommer, at Polens selvforståelse som den østeuropæiske stormagt og en ledende del af EU lider et gevaldigt knæk.

Efter den tidligere regerings konfrontationer med Tyskland og Rusland har Polen under Donald Tusk ellers placeret Polen solidt på det europæiske skakbræt.

Rusland har måttet erkende, at det ikke bare kunne springe Polen over og tale direkte med Tyskland og Frankrig. De har lært, at uden gode forbindelser til Polen kunne de ikke have gode forbindelser til EU.
"Men den position bliver undergravet. Polen er i alvorlig fare for at blive marginaliseret. Det er ikke synligt endnu, men det vil meget hurtigt blive meget tydeligt", vurderer Bartek Nowak.

Den absolut vigtigste $\varnothing$ konomiske og politiske partner, Tyskland, har nu blikket stift rettet mod eurozonen, og Polen bliver mindre relevant.

"Polen er et stort land, klart det største af de 12 nye EU-lande, og mener at spille en central rolle i forholdet mellem EU og Rusland og resten af det østlige Europa. Men når Polen ikke befinder sig i kernen inden for EU, så bliver Polen automatisk mindre interessant, også for USA, Rusland og andre lande i Østeuropa”, konstaterer Nowak.

\section{Traktatændringer}

Forsøget på at undgå, at det nye magtcenter i eurolandene får EUsamarbejdet til at knække over, bliver paradoksalt nok drevet frem af netop den, der er trådt i karakter som den økonomiske regerings ubestridte leder.

Den tyske kansler, Angela Merkel, kan ikke have, at det forstærkede samarbejde mellem eurolandene fungerer som et mellemstatsligt arrangement, helt uden for det demokratiske og retlige system, der er bygget op i den Europæiske Union.

Merkel er især optaget af, at EU/eurogruppens mulighed for at 
gribe ind i de enkelte landes finanslove bliver forankret i traktaten.

"Vi vil have et stærkere Europa, der har bedre muligheder for at gribe ind", forklarede kansler Angela Merkel.

Så hun insisterer på, at det nye samarbejde skal arbejdes ind i EUtraktaten og åbner dermed et nyt slagsmål om traktaten - mindre end to år efter at Lissabon-traktaten trådte i kraft efter ti års tilløb.

Merkel er uden tvivl drevet af et oprigtigt ønske om en ordentlig og demokratisk anstændig håndtering af de nye realiteter i europæisk politik.

Men centralt placerede kilder peger på, at Tyskland desuden har en klar pragmatisk interesse i at involvere nordeuropæiske lande uden for euroen - såsom Danmark og Sverige - der i debatten om budgetdisciplin er naturlige allierede for Tyskland.

De fleste andre betragter imidlertid projektet som dødfødt. Irske diplomater er citeret for, at en traktatændring af den karakter ganske givet vil kræve en folkeafstemning. Og at den ikke kan vindes i en situation, hvor irerne i forvejen er vrede over massive nedskæringer, som de opfatter som dikteret fra Bruxelles.

Også i et eller flere nationale parlamenter kan traktatændringer falde. Balladen i Finland og Slovakiet, hvor den seneste redningspakke væltede regeringen, står i frisk erindring.
De øvrige lande har ikke desto mindre accepteret at drøfte behovet for 'begrænsede' ændringer af traktaten. Og det vil sætte sit præg på det danske formandskab.

Det er langt fra givet, at traktatændringerne bliver 'begrænsede'. Europa-Parlamentet der har fået indflydelse på forhandlingerne om traktatændringer, arbejder for at ændringerne får et bredere sigte end blot at gribe ind i uansvarlige landes finanslove.

Under topmødet i oktober frygtede parlamentets formand, Jerzy Buzek, at magtkoncentration i eurogruppen kommer til at splitte Europa og ødelægge sammenhængskraften i EU.

"En traktatændring skal gøre den $\varnothing$ konomiske union og den økonomiske regering til et fælles projekt, der kan samle Europa", siger parlamentets formand.

\section{Bag lukkede døre}

Og formanden har bred opbakning i Parlamentet, siger SF's medlem Emilie Turunen. "Situationen lige nu er, at Merkel og Sarkozy aftaler det hele bag lukkede døre. Derfor er et meget bredt flertal i Parlamentet optaget af, at vi får en åben og demokratisk proces, der involverer Kommissionen, de 27 lande og det folkevalgte parlament".

Kommissionen trækker i samme retning. Ligesom Tyskland er kommissionen optaget af, at den store 
krisepakke med radikale løsninger på gældskrisen i Grækenland og andre eurolande ikke skal være enden, men begyndelsen på endnu større reformer af EU.

"Vi skaber nu en stærk, central styring af eurolandenes økonomier, for det er nødvendigt for at undgå en ny krise. Hvis vi skal beskytte det indre marked og den samlede union, må vi forankre alt dette i traktaterne", forklarer kommissionsformand Barroso.

"Der er en europæisk fornyelse på vej. Nu er det meget vigtigt at sørge for, at den kommer til at omfatte alle 27 EU-lande", siger han.

Professor Marlene Wind, der leder Center for Europæisk Politik på Københavns Universitet, betragter det som sandsynligt, at der bliver behov for traktatforhandlinger allerede i foråret.

"Det kan hurtigt komme til traktatforhandlinger, som Danmark kan få ansvar for under vores formandskab. I så fald kan vi jo lige så godt prøve at påvirke dem i en retning, der give os og andre lande uden for euroen mere indflydelse".

Marlene Wind påpeger, at der nu er 'rigtig meget pres' i retning af stramninger af traktaten, fordi eurolandene mangler et system til effektiv håndhævelse af euroreglerne. Hun mener, at Danmark sammen med andre lande uden for euroen burde gribe chancen for at kræve et nyt system, som sikrer alle indflydelse.
"Vi kommer meget hurtigt til at se en proces i retning af en form for " økonomisk regering' i EU. Sådan som situationen er nu, er der reelt meget lidt eller ingen indflydelse til andre end Tyskland og Frankrig. Det er bare ikke holdbart i det lange løb. Og det kan Danmark ikke leve med på længere sigt”, siger Marlene Wind.

Men traktatændringer er helt åbenlyst ikke statsminister Helle Thorning-Schmidts kop te.

"Det vigtigste lige nu er at løse den konkrete udfordring, vi står overfor - en meget alvorlig gældskrise. Jeg mener ikke, at traktatændringer løser den problemstilling", siger hun.

\section{Tillidskrise}

Formandskabet bliver ikke lettere af, at Helle Thorning og hendes regering skal operere i et historisk klima af mistillid og vrangvillighed.

Et godt eksempel er, at de øvrige EU-lande nægter at optage Rumænien og Bulgarien i den europæiske pasunion, Schengen-samarbejdet. Kommissionen har konstateret, at alle tekniske krav er opfyldt og har givet grønt lys. Men de øvrige lande - med Tyskland og Frankrig i spidsen - tror bare ikke på det. I efteråret lagde de dog op til en indrømmelse - at lade pasfriheden gælde i lufthavne - men det blev blokeret af Holland og Finland.

Beslutningen om at blokere for 
Rumænien og Bulgarien er et markant brud i EU's historie, hvor mantraet hidtil har været 'mere og mere med flere og flere'.

Ingen er i dag i tvivl om, at det var en fejl at stole på grækerne, da de på grundlag af forfalskede data og urealistiske løfter blev optaget i euroland. Og uden for citat erkender centralt placerede embedsmænd i kommissionen nu også, at det var en fejl at optage Rumænien og Bulgarien i EU i forventning om, at de - efter optagelsen i 2007 - ville gøre noget alvorligt ved den organiserede kriminalitet og korruption, der rækker langt ind og højt op i statsadministrationen.

Belært at bitre erfaringer er stemningen i dag, at man ikke kan stole på dem. På hinanden.

"Det her stikker meget, meget dybere end bare spørgsmålet om, hvornår rumænerne og bulgarerne kan komme med i Schengen. Det handler om følelser og politik; og om, at borgerne i de forskellige medlemslande mister tilliden til hinanden”, siger Hugo Brady, seniorforsker og ekspert i retlige og indre anliggender ved tænketanken CER i London, til Politiken.

Eller som den polske europaminister, Mikolaj Dowgielewicz, udtrykte det:
"EU kan ikke fungere uden tillid. Med andre ord: Tillid er den europæiske valuta: Det er den politiske og sociale lim i det europæiske projekt".

Som en illustration af, hvordan tillidskrisen kan udvikle sig, har rumænerne ophævet det indre marked for tulipaner. Det skete i timerne efter, at hollænderne meldte ud, at de ville blokere for Rumæniens og Bulgariens optagelse i Schengen. På det tidspunkt opdagede de rumænske myndigheder pludselig en mystisk bakterie i de hollandske tulipaner, som er en af landets vigtigste eksportvarer, og besluttede at standse lastvognene med hollandske tulipaner ved grænsen.

Hvis Helle Thorning Schmidt kan lukke formandskabet med ordene, at økonomien ikke er brudt sammen og at det europæiske samarbejde - mellem de 27 - fortsat fungerer nogenlunde intakt, vil det være en umådelig bedrift.

Sådanne ord vil næppe indskrive sig i historiebøgerne på samme måde som københavnerkriterierne og udvidelsen mod øst.

Men det vil være stort.

Jens Bostrup er Europa-redaktør på dagbladet Politiken og har dekket europaisk økonomi og politik siden 1989. 